\title{
The Light/Dark cycle disruption affects hepatic function both in metabolic parameters and tissue structure in a nocturnal desert rodent: Gerbillus tarabuli
}

\author{
Amina Derbouz Rouibate ${ }^{1,2}$, Nadir Benhafri ${ }^{1,2}$, \\ Saliha Ouali-Hassenaoui ${ }^{1}$, Aicha Dekar-Madoui ${ }^{1}$
}

${ }^{1}$ USTHB, Faculty of Biological Sciences, Laboratory of Biology and Physiology of Organisms, Neurobiology Team, BP 32, El Alia, 16111 Bab Ezzouar, Algiers, Algeria

${ }^{2} \mathrm{Dr}$ Yahia Fares University of Medea, Faculty of Sciences, Algeria

\begin{abstract}
Introduction. Biological rhythms, such as Light/Dark (LD) cycles, are an integral component of virtually all aspects of life. These rhythms are controlled in large part by circadian clocks, allowing the organism to adapt its internal rhythmic metabolism to changes in the external environment created by daily fluctuations in the LD cycle. Therefore, changes in the daily duration of the lighting could lead to adverse health consequences. The aim of the study was to investigate, in a nocturnal desert rodent, Gerbillus tarabuli, the effects of the LD cycle disruption on the structure of the hepatic tissue and the content of carbohydrate and lipid parameters as indicators of metabolic state.

Material and methods. The present study was conducted on two gerbil groups: control group was exposed to a standard lighting cycle (LD: 12:12), and the shifted group was subjected to a chronic disrupted LD cycle, alternating a standard cycle (LD: 12:12) with a modified cycle (LD: 20:4), i.e., the light phase of 24-h cycle was prolonged by $8 \mathrm{~h}$ on every second day during a period of 12 weeks. We used: (i) routine histology and histochemical staining for tissue analysis; (ii) immunohistochemistry (IHC) for MPO detection; (iii) biochemical methods for hepatic glycogen and lipids extraction and quantification. Blood metabolic parameters were assessed by enzymatic methods.

Results. Our structural results indicate in the shifted group an alteration of tissue architecture, showing widely scattered inflammatory foci with many dilated sinusoids and prominent leukocyte infiltration with connective fibrotic extension. IHC revealed also increased hepatic myeloperoxidase (MPO) expression confirming neutrophils' presence. In parallel, the histochemical study revealed a strong depletion of hepatocytic glycogen and lipid inclusions; these observations were also supported by the measurements of glycogen and total lipids in extracted tissue indicating a reduction in liver content. These results were accompanied by a decrease in body weight relative to the reduction of food intake, as well as hyperglycemia and some alterations in serum lipid parameters (triglycerides and cholesterol) suggesting a metabolic disturbance.

Conclusion. We conclude that a phase difference between the endogenous activity rhythm of the species and the daily cycle of illumination has a strong impact on the liver morphology as well as on the metabolic activity of liver cells. (Folia Histochemica et Cytobiologica 2020, Vol. 58, No. 3, 182-197)
\end{abstract}

Key words: Gerbillus tarabuli; liver, photic desynchronization; liver structure; metabolism; myeloperoxidase

Correspondence address: Amina Derbouz Rouibate,

Aicha Dekar-Madoui,

USTHB, Faculty of Biological Sciences,

Laboratory of Biology and Physiology of Organisms,

Neurobiology Team, BP 32, El Alia, 16111 Bab Ezzouar, Algiers, Algeria

e-mails: mounader@hotmail.com (A. Derbouz Rouibate), adekar@usthb.dz (A. Dekar-Madoui) 


\section{Introduction}

Most living species have an internal circadian clock, which allows coordinating their physiology and behavior to the alternation of day and night.

The internal clock is synchronized by environmental factors. In mammals, light-dark alternation is the main environmental signal used by the central circadian oscillator to synchronize its endogenous rhythm with the environmental rhythm [1-3]. Thus, changes in the daily duration of the exposure to light will have a strong impact on body's physiology [4]. The diurnal physiology is therefore cyclical and organized in a coordinated way so that the period of natural light corresponds to that of awakening, food intake, and energy storage while the night period is associated with sleep, fasting and the use of energy reserves in the short term. This temporal coordination which is opposite in phase in nocturnal animals, is ensured, to a very large extent, by the main circadian clock, located in the suprachiasmatic nuclei (SCN) of the hypothalamus [5] and in the peripheral clocks identified in the majority of peripheral organs, including the liver [6].

The liver was among the first peripheral organs in which molecular oscillations of clock genes were demonstrated [7]. It is interesting to note that circadian regulation plays a large role in liver metabolism. Indeed, glucose, bile acids, lipids, and cholesterol are all subject to timed circadian control [8].

Recent studies suggest that changes in circadian rhythm would have adverse health consequences, causing metabolic dysfunction. These shifts in peripheral tissues result in asynchrony between the master clock and the peripheral clocks [9].

However, the advents of artificial lighting and current lifestyles have led to significant, sometimes extreme, changes in our diurnal habits. Thus, many people working at night or performing rotating shifts, such as the police, doctors and emergency medical technicians have profoundly disturbed daily rhythms $[10,11]$. They represent a significant portion of the population that must work at a time when humans have evolved to sleep, and are required to sleep when the suprachiasmatic nuclei promotes awakening. In addition, epidemiological studies from shift workers suggest that prolonged exposure to light at night increases the risk of breast cancer [12], sleep disturbances [13], cardiovascular disorders [10, 14], and mood disorders [15]. Additionally, the increase in exposure to light at night parallels the global increase in the prevalence of metabolic syndrome and obesity $[16,17]$.

Several different animal models are used to model shift work and study the mechanism responsible for the observed correlation between shift work and metabolic dysfunctions.

This study was conducted on Gerbillus tarabuli a nocturnal species from Algerian Sahara. This area is undergoing an urban expansion causing the invasion of the ecological niches of wild species adapted to the nocturnal environment and necessarily suffering from growing light pollution, these lighting effects undeniably have effects on the biodiversity, and it would be naïve to believe that one can illuminate the night environment without causing impacts. For this reason, this rodent seems a useful model to study the metabolic effects of shiftwork in humans. We want to explore the effect of artificial and irregular light schedules on the morphofunctional aspects of the gerbil's liver.

\section{Material and methods}

Animals. The current study was performed on a nocturnal desert animal: Gerbillus tarabuli. These animals were captured in April, in the desert region of Béni-Abbès (240 km south-east of Béchar and located $1200 \mathrm{~km}$ southwest of Algiers, $30^{\circ} 07^{\prime} \mathrm{N} 2^{\circ} 10^{\prime} \mathrm{W}$ ). It is a region characterized by an arid climate. We have used 19 mature animals, of both sexes of mean body weight $42 \mathrm{~g}$. The animals were cared for according to the recommendations of the Association Algérienne des Sciences en Expérimentation Animale (AASEA) (http://www.aasea.asso.dz/).

Experimental design. In captivity, for 4 weeks, all animals were housed individually in $12 \mathrm{~h}$ light- $12 \mathrm{~h}$ dark cycle (lights on at 00:00 and lights off at 12:00), and temperature-controlled cages $\left(22 \pm 2^{\circ} \mathrm{C}\right)$, fed on barley grains ad libitum without water. Then, the animals were randomly separated into two groups and placed in chronobiotic rooms. The first group (control; $n=9$ ) was maintained in standard circadian cycle (LD: $12: 12$ ), and the second one (shifted; $\mathrm{n}=10$ ) was subjected to a chronic disrupted Light/Dark cycle, alternating a standard cycle (LD: 12:12) with a modified cycle (LD: 20:4), i.e., the light phase of the 24-h cycle was prolonged by 8 hours every second day during a period of 12 weeks (Fig. 1).

The sacrifice of anesthetized animals was performed at the end of the experiment between 9-12 $\mathrm{h}$ when the LD cycle of control and shifted groups came together.

The study targeted the body mass, food intake, plasma parameters, histological and immunohistochemical features, which were performed on 5 gerbils of the control group and 6 gerbils of the shifted group.

The biochemical tissue analysis requiring the use of the whole fresh liver was performed on 4 other gerbils of each group.

Body mass and food intake. The body mass and the food intake were measured by weekly individual weighing. In 


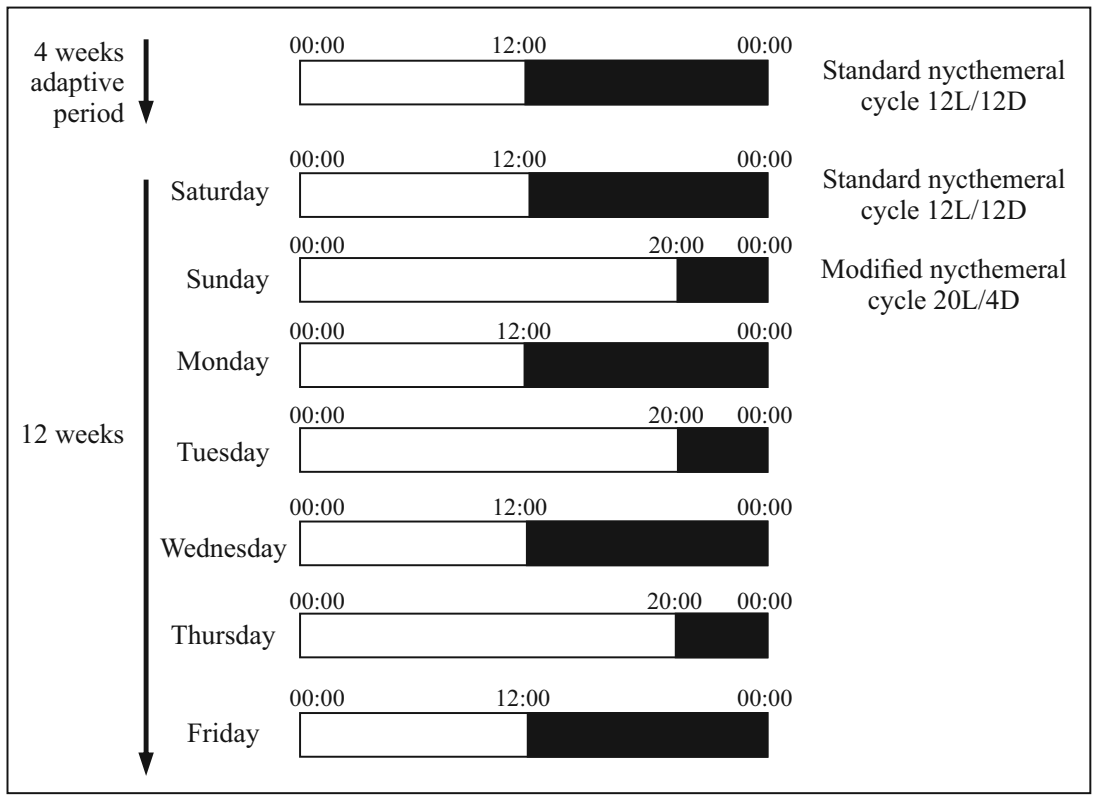

Figure 1. Time schedule of lighting conditions over 16 weeks, including 4 weeks of adaptive period and 12 weeks of experimental conditions. A daily period of darkness is indicated by black bars.

order to estimate food consumption, we gave $50 \mathrm{~g}$ of barley each week.

Blood metabolic parameters. Blood was collected by retro-orbital puncture into heparin tubes and kept on ice, and subsequently centrifuged for $10 \mathrm{~min}$ at $2500 \mathrm{rpm}$ at room temperature (RT); the plasma was recovered and stored at $-20^{\circ} \mathrm{C}$ until measurements.

Blood glucose was measured at 10:00 am using a Glucometer (One Touch Ultra 2, LifeScan, Zug, Switzerland) by retro-orbital bleeding.

Cholesterol and triglycerides were assayed by the enzymatic method using test kits from SPINREACT (S.A./S.A.U. Ctra. Santa Coloma, Spain).

Hepatic glycogen content. Gerbils were euthanized (zeitgeber time: ZT 9-12), the whole liver was removed and glycogen content was assessed according to the method of Hassid and Abraham [18]. In short, liver portions weighing between $300-400 \mathrm{mg}$ were boiled in a $30 \%$ potassium hydroxide solution $(\mathrm{KOH})$ for 30 minutes to hydrolyze the glycogen. Total glycogen was precipitated by addition of $95 \%$ alcohol and then recovered by centrifugation at $2500 \mathrm{rpm}$ for $15 \mathrm{~min}$; hydrolyses of glycogen into glucose was performed by adding $2.5 \mathrm{~N} \mathrm{H}_{2} \mathrm{SO}_{4}$ solution. The solution obtained was neutralized with $2 \mathrm{M} \mathrm{NaOH}$ to $\mathrm{pH} 7.4$ and the hydrolyzed free glucose concentration was evaluated using the enzymatic colorimetric glucose oxidase method according to Trinder (1969) [19].
Hepatic total lipids content. Livers were harvested (ZT 9-12), and total lipids were quantified by the Folch method [20].

To this aim, a weighed fresh liver fragment was ground cold with a Potter-type homogenizer in the chloroform-methanol mixture (2: 1, v/v), for 24 hours, the chloroform has the property of completely dissolving protein-bound lipids, which are then precipitated by methanol.

The ground material was filtered under defatted filter paper. The extract obtained was recovered in flasks, adjusted to $25 \mathrm{~mL}$ of Folch, sealed and placed at $4{ }^{\circ} \mathrm{C}$. An aliquot of the filtrate $(5 \mathrm{~mL})$ was washed with distilled water. After stirring and centrifugation at $2500 \mathrm{rpm}$, the upper phase was removed; the lower phase was collected in previously weighed tubes, and allowed to evaporate in a ventilated oven at $60^{\circ} \mathrm{C}$. After evaporation, the tubes were reweighed. The amount of total lipids was determined by the difference between the two values.

\section{Morphological studies}

Histochemical analysis. Liver pieces of both groups of animals were immersed in Bouin's and Ciaccio's fluids [21] and, after typical procedure, embedded in paraffin. Sections of $4 \mu \mathrm{m}$, obtained on a microtome, were stained with Masson's trichrome method as topographic stain, Periodic acid-Schiff (PAS) was used to stain for glycogen and Sudan Black B was used to detect lipids in the samples fixed in Ciaccio's fluid [21].

Structural analysis. Livers of both groups of animals were fixed by intracardiac perfusion with $4 \%$ paraformaldehyde 
and $2.5 \%$ glutaraldehyde in a $0.1 \mathrm{M}$ phosphate buffer $(\mathrm{pH}$ 7.2-7.4) and subsequently post fixed in $1 \%$ osmium tetroxide $\left(\mathrm{OsO}_{4}\right)$ for two hours and embedded in epoxy resin blocks. Semithin sections of $1 \mu \mathrm{m}$ were cut with an ultramicrotome (8800 Ultratome III LKB, Bromma, Sweden) and these semithin sections were stained with Toluidine Blue.

The analyses were performed on two sections per animal with a total of 80 images for controls and 96 images for shifted group.

All histological samples were examined by Zeiss Axoplan microscope (Zeiss, Jena, Germany) and photographed with High-Resolution Optics Microscope Camera (MA88-500/ /Premiere ${ }^{\circledR}, 5.0$ Megapixels with a $1280 \times 1024$ resolution) using TSView version 6.2.4.5 (Tucsen. Imaging Technology Co. Limited, Fuzhou, China). None of the images collected were digitally manipulated.

Immunohistochemistry. Fixed in $4 \%$ paraformaldehyde for $48 \mathrm{~h}$, paraffin-embedded liver samples were cut into $2 \mu \mathrm{m}$-thick tissue sections and mounted on Silanized Slides. Tissue sections were deparaffinized and heat induced epitope retrieval was carried out in EnVision ${ }^{\mathrm{TM}}$ FLEX Target Retrieval Solution (TRS), high pH (Dako K8004, Glostrup, Denmark) for $40 \mathrm{~min}$ at $95-99^{\circ} \mathrm{C}$ using the Dako PTLink apparatus, followed by a $20 \mathrm{~min}$ cool down and rinse in phosphate-buffered saline (PBS). Endogenous peroxidase activity was blocked by incubation in $3 \% \mathrm{H}_{2} \mathrm{O}_{2}$ for $10 \mathrm{~min}$. Primary antibodies, polyclonal rabbit anti-human myeloperoxidase (MPO, ready-to-use prediluted primary antibody, Dako code IR511) were applied for $30 \mathrm{~min}$ on the tissue slides.

Sections were washed in PBS solution before incubation with the secondary antibody (EnVision FLEX/HRP SM802, K8000; Dako UK Ltd) for $30 \mathrm{~min}$ at room temperature, washed and revealed with 3,3'-diaminobenzidine peroxidase substrate (Envision ${ }^{\mathrm{TM}}$ FLEX DAB + Chromogen DM827, Dako) solution to yield an insoluble brown deposit. Tissue sections were counterstained with Groat's hematoxylin for few seconds. The immunostaining was observed with Zeiss light microscope.

Reactivity for MPO was tested by the omission of primary antibodies and incubation in normal rabbit serum or with irrelevant secondary antibodies. These sections did not show any labeling.

The MPO immunoexpression was quantified using Image $\mathbf{J}$ software (NIH, Bethesda, MD, USA) that measures the average darkness of the image due to DAB signal. The image was inverted to clean out the white noise, then the regions of interest were drawn to define the stain color, the background and the counterstaining with hematoxylin were subtracted. The labeling was measured for two sections per animal with a total of 80 images for controls and 96 images for shifted group using a $40 \times$ objective.
Statistical analysis. Statistical analysis was performed by testing first the distribution of all variables for normality. Two-way analysis of variance on ranks with repeated measures was used to test the effect of time and desynchronization in addition to the interaction between factors on body weight, food intake or metabolic parameters. One-way analysis of variance was used to test the effect of desynchronization on hepatic glycogen and total lipid content between the two groups at the end of experimentation. The two analyses were followed by Tukey post-hoc test.

One-way ANOVA was used to quantify the intensity of the immunostaining of hepatic cells.

All data are expressed as the means \pm SEM, with a statistically significant difference defined as a value of $\mathrm{P}<0.05$ ( $\mathrm{R}$ software version 3.5.1).

\section{Results}

\section{Photic desynchronization effects on body weight and food intake}

Comparative change in body weight for 12 weeks

Body weight, body weight loss, and food intake curves of control group $(n=5)$ and shifted group $(n=6)$ are shown in Fig. 2. The body weight in both groups was comparable at the beginning of the study (48.14 \pm $4.05 \mathrm{~g} v s .44 .61 \pm 3.15 \mathrm{~g}$ ) and throughout experimental light conditions.

The analysis of the body weight evolution reveals in the control group a slight decrease of $-2.83 \%$ with a final body weight of $44.18 \pm 3.14 \mathrm{~g}$. In the shifted group this decrease is greater and achieves a loss of $12.63 \%$ with a final weight of $38.98 \pm 4.38 \mathrm{~g}$ (Fig. 2A).

We observed a significant effect of desynchronization on the evolution of body weight and body weight loss ( $\mathrm{p}<0.001$; two-way repeated measures of ANOVA on ranks). Tukey post hoc test showed a significant effect of circadian rhythm disruption on body weight loss $(\mathrm{P}<0.05)$ in respect to the first week in the shifted group. In addition, the post hoc contrast function indicates a significant difference between the two groups for body weight loss during experiment ([week (1-3) - week 10], $\mathrm{P}<0.05$, Fig. 2C).

\section{Comparative change in food intake for 12 weeks}

The shifted group displayed a $9.20 \%$ decrease in the amount ingested. Conversely, compared to the control group (12:12: LD), experimental disruption (12:12/ 20:4: LD) showed higher ingested amounts during the whole period of shifting with significant effect of desynchronization on the evolution of food consumption $(\mathrm{P}<0.01)$. Nevertheless, Tukey posthoc test didn't show significant differences between the two groups (Fig. 2B). 


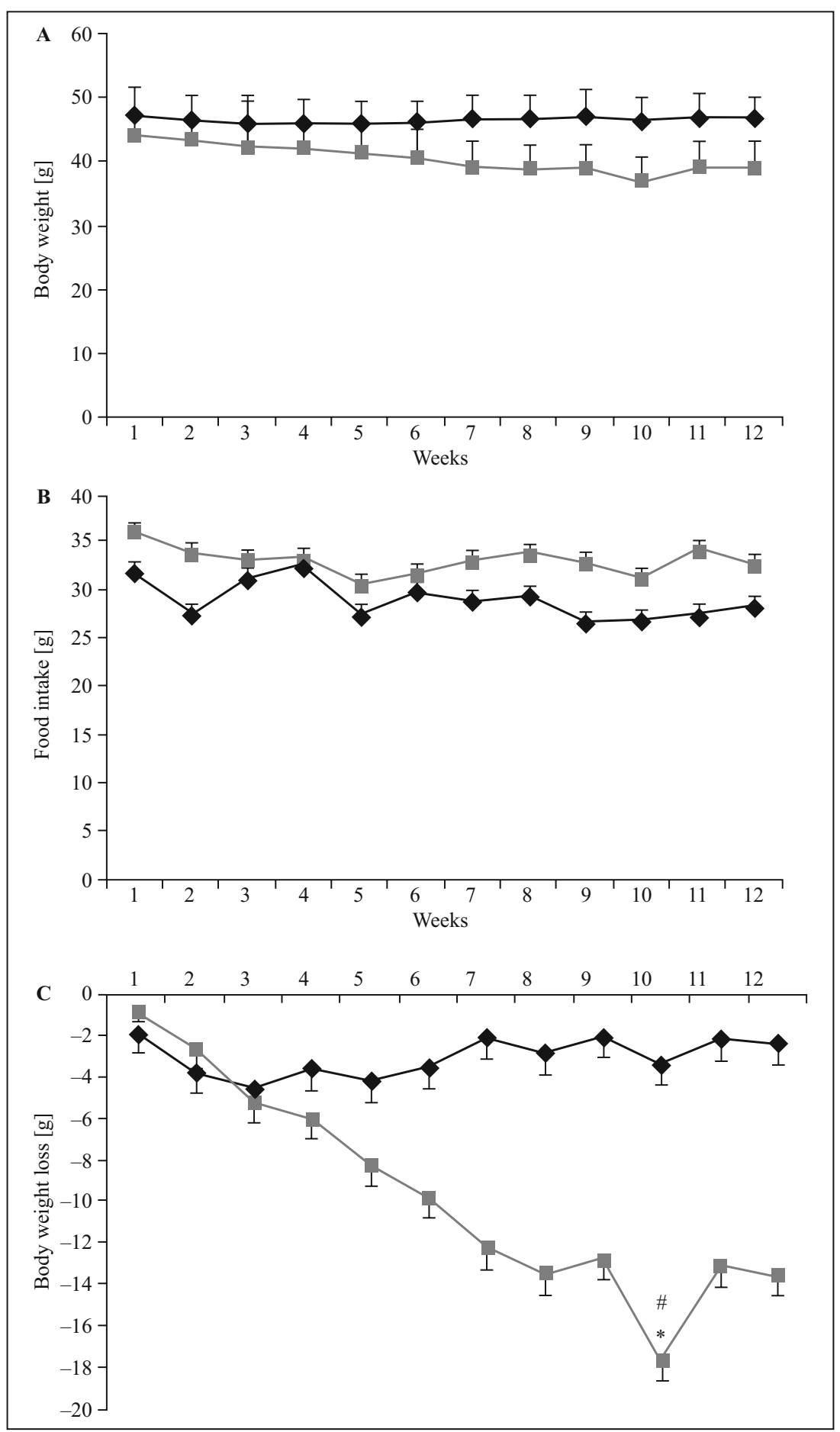

Figure 2. Changes in body weight (A), food intake (B) and body weight loss $(\mathbf{C})$ in control group (dark line, $\mathrm{n}=5$ ), and shifted group (gray line, $\mathrm{n}=6$ ). Profiles were measured during 12 weeks. Values are expressed as mean $\pm \mathrm{SEM},{ }^{*} \mathrm{P}<0.05$ $v s$. week 1 in the shifted group (Two-way repeated measures ANOVA on ranks), ${ }^{\#} \mathrm{P}<0.05$ vs. control group during experiment [week (1-3) - week 10] (post hoc contrast function).

Photic desynchronization effects on blood glucose, cholesterol, and triglycerides levels

Blood glucose, cholesterol, and triglycerides curves of control group $(n=5)$ and shifted group $(n=6)$ are presented in Fig. 3. Two-way ANOVA on ranks
(Aligned Rank Transform) indicates a significant effect of desynchronization only for triglyceride levels $(\mathrm{P}<0.05)$. However, no time effect is observed on all metabolic parameters $(\mathrm{P}>0.05)$. 


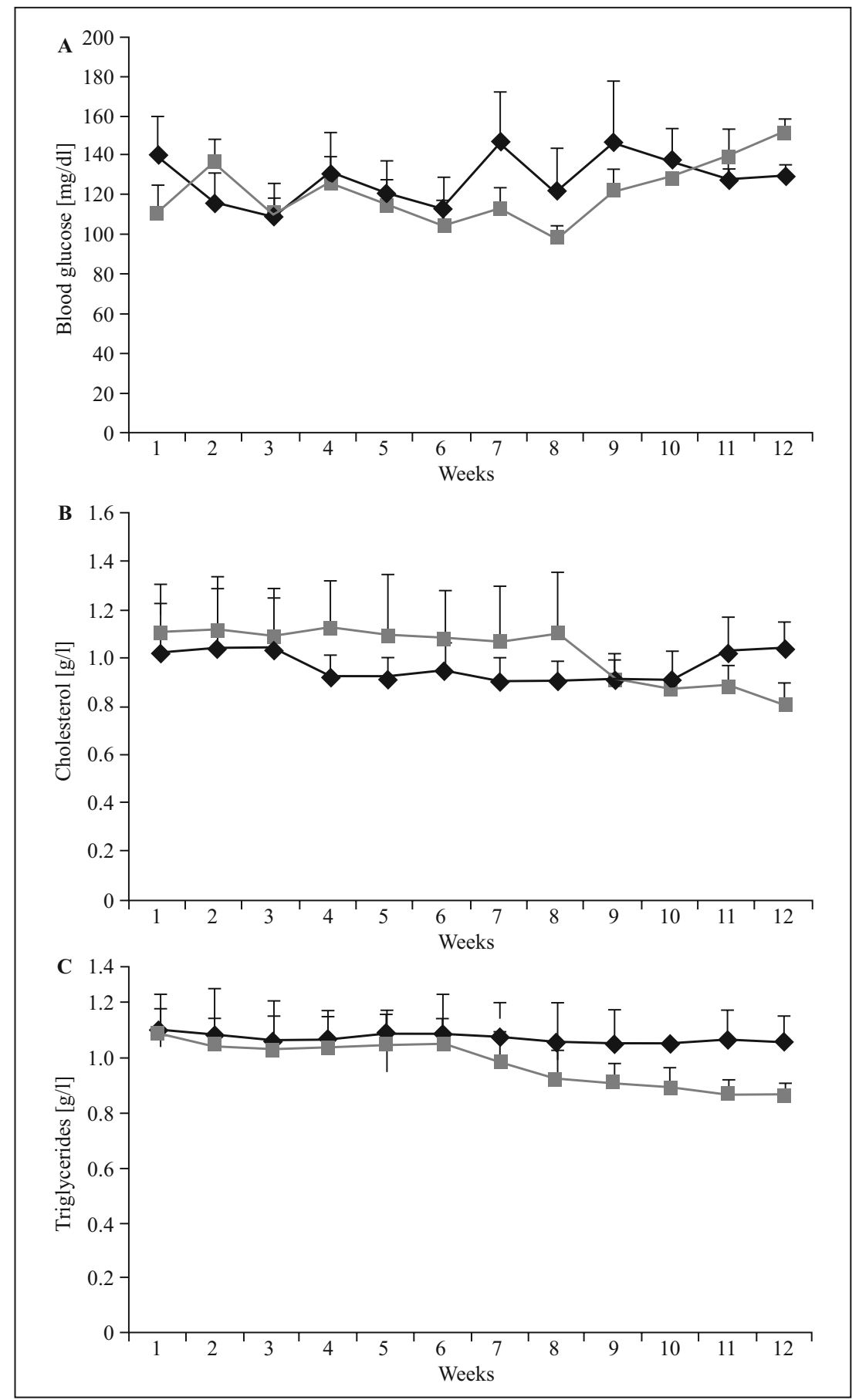

Figure 3. Effect of 12 weeks of photic desynchronization on blood metabolic parameters in control group (dark line, $n=5)$, and shifted group (gray line, $\mathrm{n}=6$ ). Glucose $(\mathbf{A})$, cholesterol $(\mathbf{B})$ and triglyceride $(\mathbf{C})$ plasma concentrations were measured as described in Methods. Profiles were measured during 12 weeks. (Values are expressed as mean \pm SEM, two-way repeated measures ANOVA on ranks).

The evolution of blood glucose levels in the two groups of gerbils, obtained after 12 weeks of experiments, was fluctuating. While blood glucose values of controls seemed stable (began at $140 \pm 20.29 \mathrm{mg} / \mathrm{dL}$ and achieved $129.8 \pm 5.54 \mathrm{mg} / \mathrm{dL})$, in the shifted group, blood glucose levels fluctuated until $8^{\text {th }}$ week. Then, blood glucose elevated progressively to reach $151.33 \pm 8.07 v s .111 .16 \pm 13.86 \mathrm{mg} / \mathrm{dL}$ at the beginning, indicating a hyperglycemic state (Fig. 3A). 


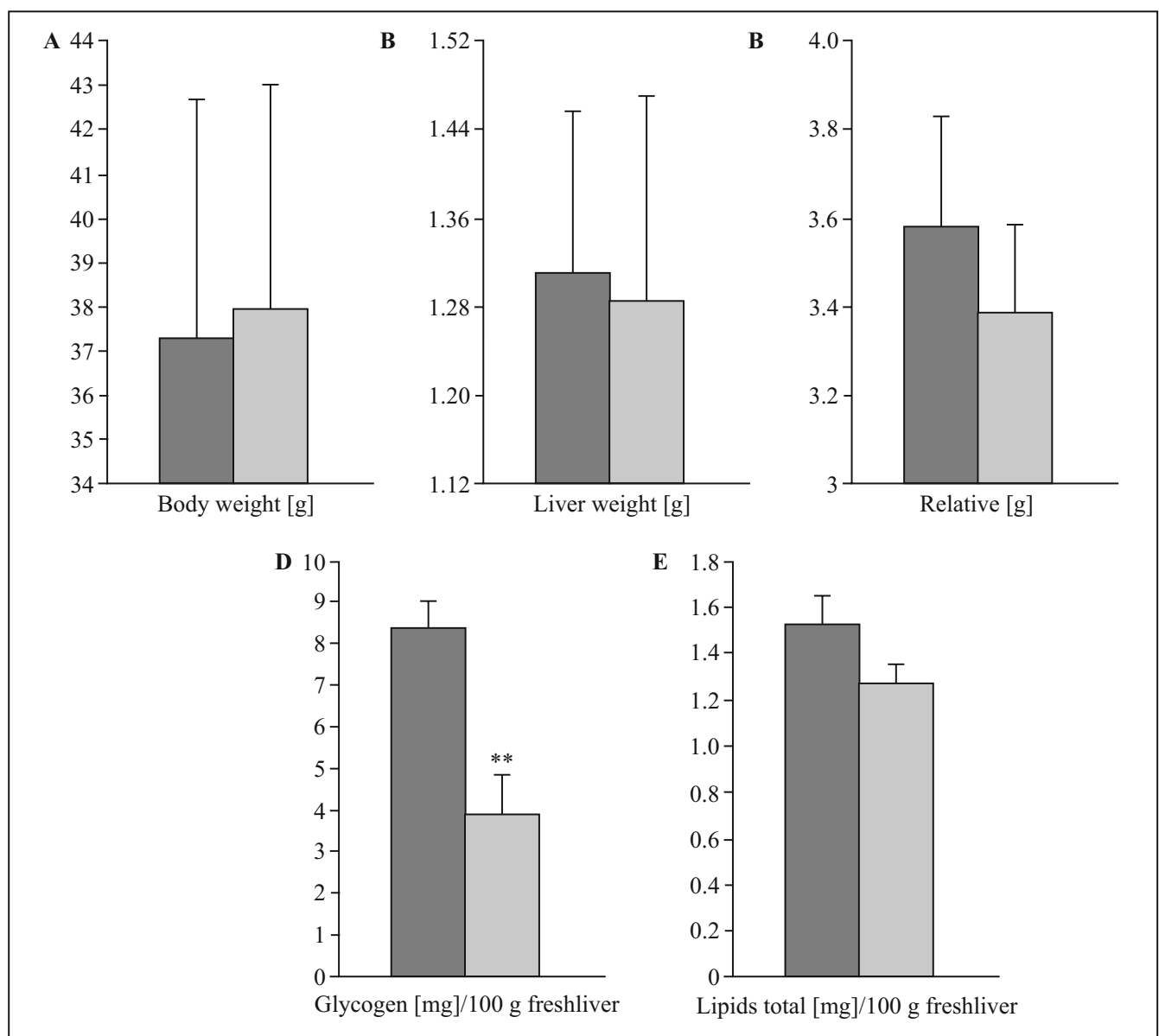

Figure 4. Effect of 12 weeks of photic desynchronization on the content of glycogen and total lipids in gerbil's liver. A. The body weights of control group (dark bars, $\mathrm{n}=4$ ) and shifted group (gray bars, $\mathrm{n}=4$ ) were $37.27 \pm 5.39$ and $37.95 \pm 5.10 \mathrm{~g}$ $(\mathrm{P}>0.05)$. B. The absolute weights of shifted gerbil's liver compared with controls were $1.28 \pm 0.18$ and $1.31 \pm 0.14 \mathrm{~g}$ $(\mathrm{P}>0.05)$ showing little variation. $\mathrm{C}$. The relative mean value of liver weights of control group and shifted group were $3.58 \pm 0.25 \%$ and $3.38 \pm 0.20 \%(\mathrm{P}>0.05)$. D, E. Hepatic glycogen and total lipids levels in gerbils of both batches $\left({ }^{* *} \mathrm{P}<0.01\right)$. Values are expressed as mean \pm SEM, One-way ANOVA.

For plasma cholesterol, compared to the control group which showed a stability $(1.02 \pm 0.20 \mathrm{~g} / \mathrm{L}$ at the beginning of the experiment and $1.04 \pm 0.10 \mathrm{~g} / \mathrm{L}$ at the end of 12 weeks), the shifted group showed a reduction $(1.11 \pm 0.20 \mathrm{~g} / \mathrm{L}$ at the beginning of the experiment to $0.81 \pm 0.08 \mathrm{~g} / \mathrm{L}$ at the end) thus achieving a decrease of $27 \%$ (Fig. 3B).

The shifted group showed a progressive decrease in triglyceride levels (from $1.09 \pm 0.09 \mathrm{~g} / \mathrm{L}$ at the beginning to $0.86 \pm 0.04 \mathrm{~g} / \mathrm{L}$ at the end of the experiment), giving a percentage decline of $21.11 \%$ compared to controls $(1.10 \pm 0.12$ to $1.05 \pm 0.10 \mathrm{~g} / \mathrm{L})$ (Fig. 3C).

However, Tukey post-hoc test didn't show any significant differences between the two groups for all metabolic parameters.

\section{Hepatic glycogen and total lipids content}

The relative and absolute weights of the liver of shifted gerbils showed no significant difference compared to controls (Fig. 4B and C).

After extraction at the end of the 12 weeks of experimentation, we observed a significant effect of desynchronization on hepatic glycogen content (P < 0.01; one-way ANOVA). Indeed, lower glycogen values were found in the shifted group $(3.89 \pm$ $0.98 \mathrm{mg} / 100 \mathrm{~g}$ fresh liver), representing a decrease of $53.49 \%$, compared to control group (8.36 \pm 0.67 $\mathrm{mg} / 100 \mathrm{~g}$ fresh liver). Tukey's post hoc test showed a very significant difference between the two groups.

In addition, one-way ANOVA showed no significant effect of desynchronization on hepatic total lipids 


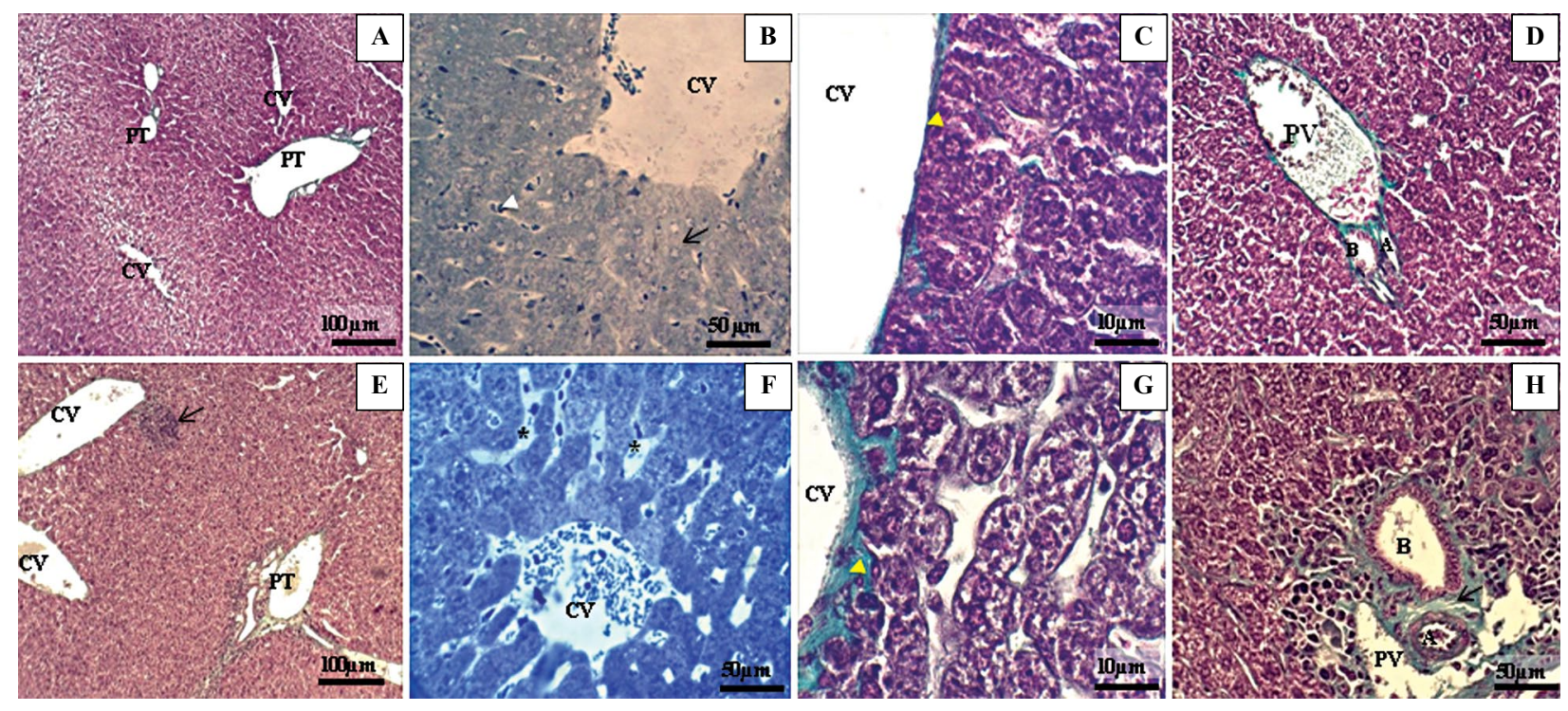

Figure 5. The structure of the hepatic parenchyma in control (upper row) and shifted (lower row) gerbils. Control gerbils. A. The overview of the hepatic tissue showed a classical lobular organization with central veins (CV) in the middle of the lobules and peripherally located portal triads (PT). B. At higher magnification, in the hepatic lobule and from the central vein $(\mathrm{CV})$ radiate the hepatocytic cords (arrow) separated by thin sinusoid capillaries (arrowhead). C. The light of the central vein $(\mathrm{CV})$ is lined by a regular endothelium with minimal presence of connective tissue (arrowhead). D. Only small amount of connective tissue is present in the portal triad that contains portal vein (PV), artery (A), and bile duct (B).

Shifted gerbils. E. The hepatic tissue architecture is strongly altered by numerous inflammatory foci (arrow). F. At higher magnification dilations of the sinusoidal capillaries are clearly visible (asterisks). G. Dilations of sinusoids and disorganization of central vein's endothelial layer (arrowhead) underlined by an abnormally thick connective layer. H. The abundance of connective tissue around the portal triad (arrow) indicates fibrosis installation. Stainings: A, C, D, E, G, and H: Masson's trichrome; B and F: toluidine blue. Scale bars: $100 \mu \mathrm{m}$ (A and E); $50 \mu \mathrm{m}$ (B, D, F and H); $10 \mu \mathrm{m}$ (C and G).

content $(\mathrm{P}>0.05)$ at the end of experimentation (control group: $1.525 \pm 0.13 \mathrm{mg} / 100 \mathrm{~g}$ of fresh liver $v s$. shifted group: $1.265 \pm 0.09 \mathrm{mg} / 100 \mathrm{~g}$ of fresh liver). After the analysis of these results, we note that in shifted gerbils, the hepatic total lipids level decreased by $17.04 \%$, though the difference with the controls was not significant $(\mathrm{P}>0.05$; Fig. 4).

\section{Morphological alterations of the liver structure}

Control animals showed the typical hepatic structure with lobules (Functional Units) centered by a central vein accompanying the portal triads (Fig. 5A). Hepatic cells are arranged in anastomosed and radial cords separated by fine vascular spaces: sinusoid capillaries, which carry blood from the portal spaces and lead into the central vein (Fig. 5B). The lobules are limited by portal spaces that contain the branches of the portal veins, hepatic arteries, and bile ducts (Fig. 5D). At the highest magnification, the lumen of the central vein was lined by a thin layer of endothelial cells (Fig. 5C).

After 12 weeks shifting, the hepatic parenchyma displayed a strong alteration evidenced by the appearance of inflammatory foci (Fig. 5E). Hepatocyte cords appeared separated by very dilated sinusoid capillaries
(Fig. 5F). Marked contingent of inflammatory cells was observed at portal triads suggesting phagocytic activity. The high magnification showed disorganization of the endothelial layer of the central vein which became bordered by an abnormally thick connective tissue layer (Fig. 5G), a pattern not seen in the controls. We also noted an extension of the connective tissue that would indicate fibrosis (Fig. 5H).

Inflammatory foci showed significant perivascular and intra-lobular leukocyte infiltration (Fig. 6A) and numerous Kupffer cells in dilated sinusoidal capillaries (Fig. 6B). We also noted marked foldings of the sinusoidal endothelium indicating an increased communication surface between the central vein and the sinusoids (Fig. 6C). The number of hypertrophied cells had increased (Fig. 6D).

On semithin sections hepatocytes displayed a very basophilic cytoplasm rich in heteromorphic granulations (Fig. 6E). Several binuclear cells showed perinuclear dilation extended to the cytoplasm that may probably be an extension of the endoplasmic reticulum (ER). Stellate cells are recognizable by their star-shape with dense nucleus and fat-rich cytoplasm (Fig. 6F). 

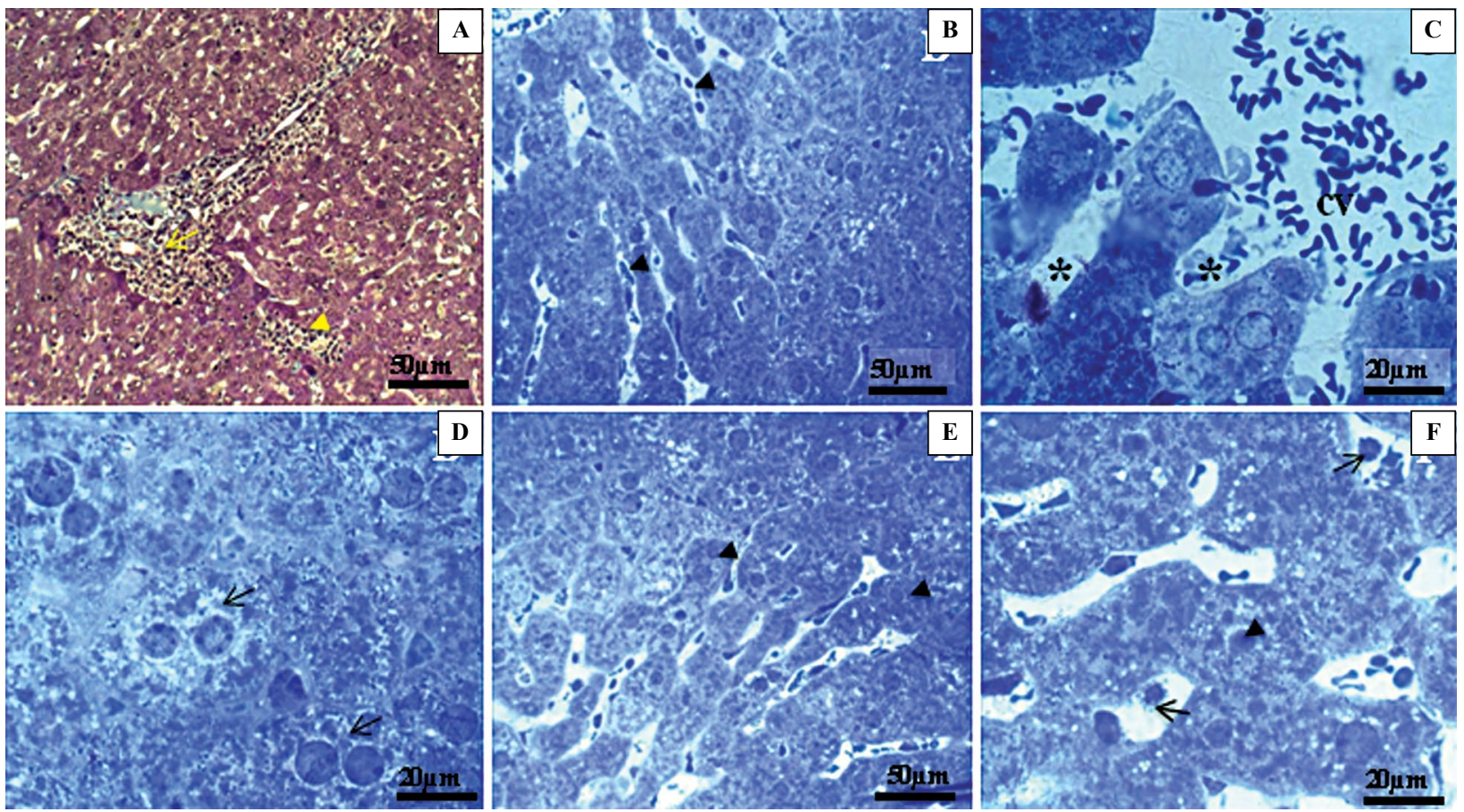

Figure 6. Histological and semithin sections showing the effect of circadian rhythm disruption on the structure of liver tissue in shifted gerbils. A. Microphotographs show large inflammatory foci with perivascular (arrows) and intralobular (arrowhead) infiltrated leukocyte clusters. B. Abundance of Kupffer cells (arrowhead). C. Great communication surface between a large central vein (CV) and sinusoids (asterisks). D. The abundance of hypertrophied cells binucleated or with hypertrophied nuclei (arrows). E. Semithin sections showed very basophilic hepatocytes's cytoplasm (arrowheads) due to the abundance of ribosomes. Note the centrifugal chromophilia in the acinus. F. The high magnification reveals perisinusoidal stellate cells (arrows). Chromophilic hepatocytes are rich in organelles; their nuclei are surrounded by a granulated cytoplasm (arrowhead) which reflects the heterogeneity of its content. Stainings: A: Masson's trichrome; B, C, D, E, and F: toluidine blue. Scale bar: $100 \mu \mathrm{m}$ (A); $50 \mu \mathrm{m}$ (B and E); $20 \mu \mathrm{m}$ (C, D and F).

Histochemical analysis by PAS staining revealed important purplish red granular inclusions corresponding to glycogenic deposits in the control gerbils (Fig. 7A, B). In contrast, in shifted gerbils only few fine cytoplasmic granulations were detected indicating a glycogenic depletion (Fig. 7E, F). In addition, the intensity of the Sudan Black B reaction was more pronounced in control gerbils (Fig.7C, D), compared to shifted gerbils (Fig.7G, H) that showed fine lipid inclusions dispersed in the cytoplasm.

\section{Immunohistochemical hepatic expression \\ of myeloperoxidase}

The immunohistochemical labeling of myeloperoxidase in both groups revealed a significantly increased number of MPO positive neutrophils and hepatocytes $(173.03 \pm 2.26$ and $115.12 \pm 2.24$ respectively, Fig. $8 \mathrm{~B}$ and $\mathrm{C}$; $\mathrm{P}<0.001)$ expressed by a positive brown cytoplasm in the shifted group compared to the control group that showed MPO negative expression in neutrophils and hepatocytes $(159.70 \pm 3.10$ and $102.76 \pm 0.98$ respectively, Fig. 8A). Also MPO im- munoreactivity increased with progression of hepatic fibrosis in shifted group.

\section{Discussion}

Circadian rhythms are biological events that are constantly repeated over a 24-hour period and are generated by an endogenous mechanism. This mechanism is managed by circadian clocks, located both at the central level (SCN) and at the peripheral organs. This system allows the body to adapt to predictable changes in its environment [22]. Indeed, the central clock is synchronized to make its periodic activities coincide with the environmental cycles, in particular the light/dark cycle [23]. This central adjustment also makes it possible to coordinate peripheral biological functions. In this study, we explored the effect of alternating a standard cycle (12L/12D) and an artificial cycle (20L/4D) for 12 weeks on the morpho-functional characteristics of gerbil's liver. The obtained results showed signs of disruption at both structural and metabolic levels. 

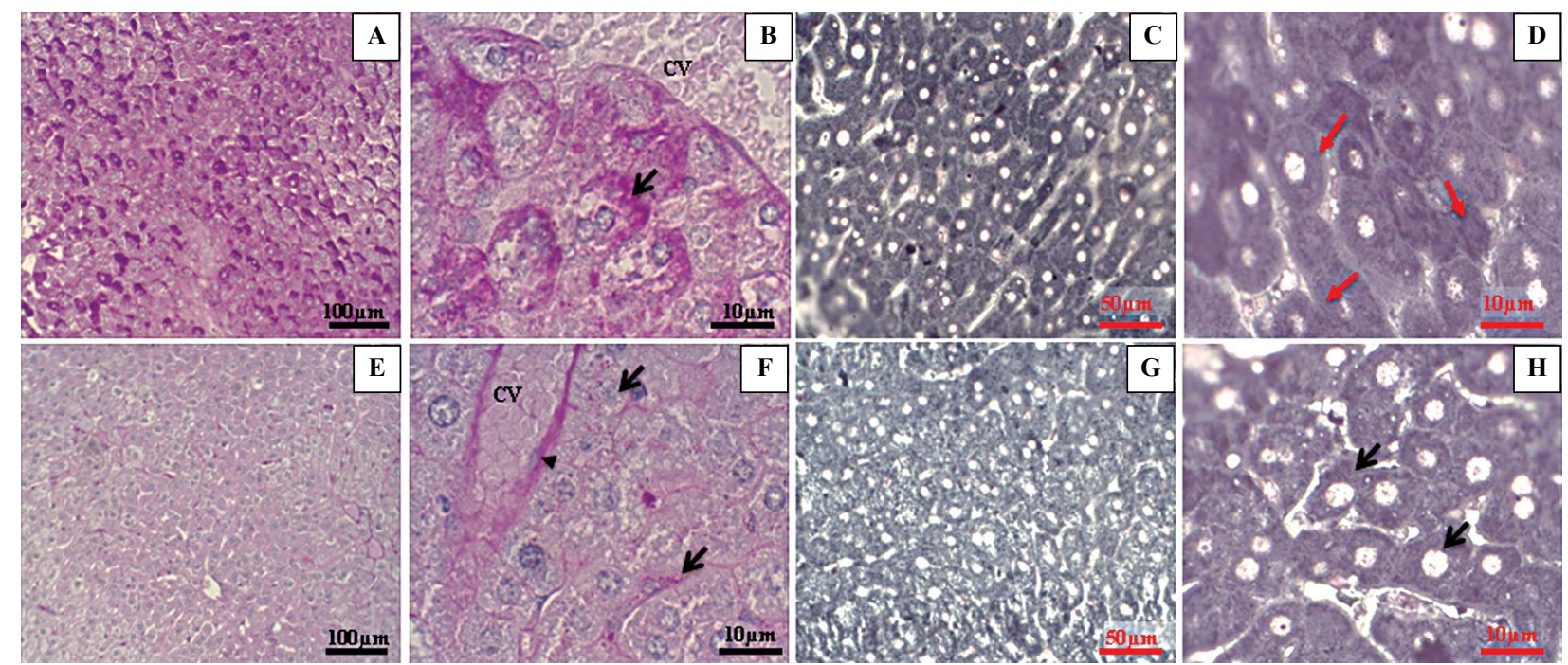

Figure 7. Histochemical photographs showing the reaction of liver tissue to PAS and Sudan Black B staining in control (upper row) and shifted (lower row) gerbils. Control gerbils. A. The overview of hepatic tissue showing the presence of important glycogen deposits. B. At higher magnification the glycogen granules sometimes occupy the whole hepatocyte (arrow). C. The overview of hepatic tissue after Sudan Black B staining showed a strong Sudanophilia. D. At higher magnification abundance of lipid inclusions completely obscure the cytoplasm (red arrows).

Shifted gerbils. E, F. We note a marked depletion of glycogen (arrows). F. PAS positivity is important in the intercellular space reflecting the abundance of extracellular matrix elements (arrowhead). G, H. Conversely, Sudan Black B staining revealed thinly positive dispersed lipid inclusions (arrows).

Stainings: A, B, E, and F: Periodic Acid Schiff (PAS); C, D, G and H: Sudan Black B. Scale bars: $100 \mu \mathrm{m}$ (A and E); $50 \mu \mathrm{m}$ (C and $\mathrm{G}) ; 10 \mu \mathrm{m}(\mathrm{B}, \mathrm{F}, \mathrm{D}$ and $\mathrm{H})$.

\section{Experimental disruption of circadian rhythms disrupts weight}

In our study gerbils subjected to disturbed circadian rhythms show a loss of $12.62 \%$ of their body mass. This result is similar to that obtained in male Siberian hamsters subjected to a short day (8L/16D) for 12 weeks; these animals lose up to $22 \%$ of their body weight [24]. Our result is also reported in a mouse model with Amyotrophic Lateral Sclerosis (ALS) maintained under a 20L/4D cycle for 120 days [25]. Likewise, the aging rats maintained with constant dim light showed a rapid body weight loss [26]. In addition, another study showed that mice habituated to an ultradian 6 meals schedule lose $>10 \%$ body mass (hypocaloric group) [27]. Otherwise, in Webster mice, a 10L/10D cycle resulted in a body weight gain [28] as in Wistar rats subjected to an ultradian feeding schedule [29]. In addition, exposure to continuous light (4-8 weeks) led to body weight gain in mice [30,31], and resulted in increased body fat [32] and more food consumption during the subjective day [30,31]. Conversely, a study using exposure to continuous bright light for 6-10 weeks in Sprague Dawley rats reports no change in body weight [33]. We also observed increased food in- take in shifted gerbils compared to the control group; a similar result is reported after long-term exposure (90 weeks) to a Light/Dark cycle (20L/4D) [34].

Altogether these results indicate that disruption of the environmental cycle has changed the feeding behavior of gerbils. This may indicate that the response of nocturnal species to desynchronization depends on the species and the phase shift protocol applied but generally reflects changes in feeding habits. According to Challet [35], the periodic supply of nutrients follows a rhythm of food intake, specific to each species, in close relation to its sleep-wake cycle.

Several studies report that altering the feeding pattern can desynchronize metabolic rhythms and potentially disrupt energy homeostasis. Indeed, a standard diet during the day alters the energy balance in mice (nocturnal species) compared to those fed only at night [9], likewise, central and peripheral clocks tick in opposite phases [36, 37].

The shifted gerbils in our experiment had a shortened awakening phase $(4 \mathrm{~h})$ probably limiting their feeding time and showed intense physical activity (personal observations) which implies excessive energy expenditure that could explain the decrease in body weight despite the increase in the amount of barley 

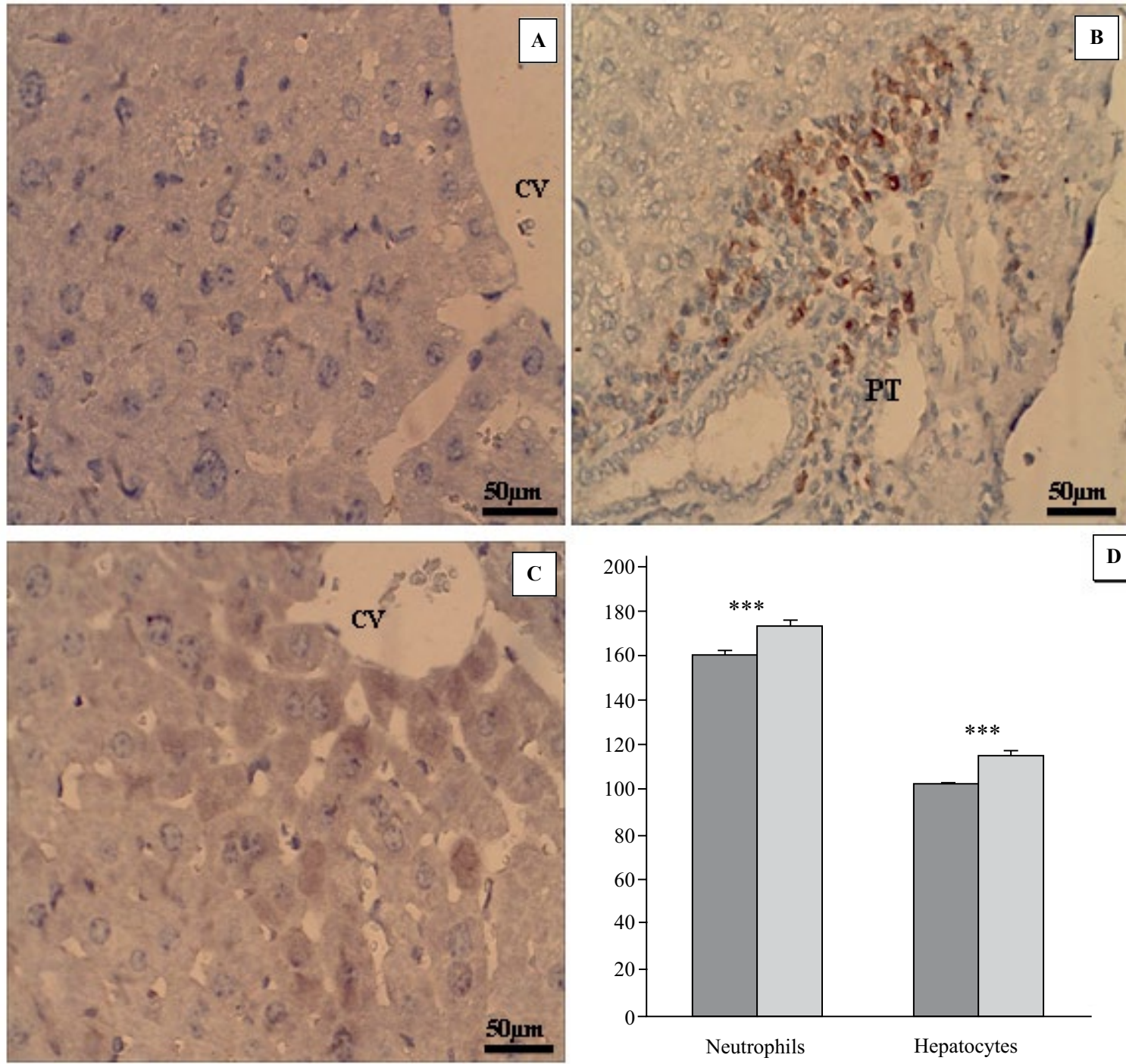

D

Figure 8. Representative immunohistochemical staining for myeloperoxidase in the liver tissue of two gerbils' groups. Compared to the control group (A), intense immunoreactivity of MPO was identified in the shifted gerbils' in neutrophils infiltrating portal tracts and the periphery of hepatic lobules (B). Moreover, the immunolabeling is also detectable in some centrolobular hepatocytes (arrow) (C). MPO cells intensity in control group (dark bars) and shifted group (gray bars) (D). Values are expressed as mean \pm SEM, One-way ANOVA, $(* * * \mathrm{P}<0.001)$.

ingested. Indeed, it was shown that a reduction in the period of food access $(<6 \mathrm{~h})$ does not allow the animals to eat an equivalent amount of food as their ad lib feed (ALF) counterparts [38].

It would, therefore, appear that the circadian time of food intake is an important factor in regulating metabolic activity probably by interaction with molecules that control diurnal liver clock. Indeed, it was reported that eating during the sleep period leads to a disruption of peripheral clocks in nocturnal mice [39].

\section{Photic desynchronization induced metabolic disturbances}

In gerbils subjected to a disturbance of the light/dark cycle, blood glucose values show a fluctuating rate during the first 8 weeks, and then tended to increase gradually to exceed the values observed in control gerbils, until the $12^{\text {th }}$ week. Indeed, it has been reported that the plasma glucose in nocturnal rats is increased by exposure to light at different times of 
the day [40]. In addition, diabetes-prone (HIP) rats develop hyperglycemia in response to a $6 \mathrm{~h}$ light advance or under constant light conditions [41].

Interestingly, the work of the Nagai group [42] was the first to show the direct involvement of SCNs in the control of glucose homeostasis, suggesting that the recorded hyperglycemia reflected a disturbance of the central clock. Indeed, mutant mice for Clock and Bmall genes in the SCN show hyperphagia as well as hyperglycemia [43].

The presence of peripheral clocks outside the suprachiasmatic nuclei is now well established. Accordingly, the liver is one of the first peripheral organs in which molecular oscillations of clock genes have been demonstrated [7]. Nevertheless, maintaining their rhythmicity in the liver seems less robust than that of the central clock [44]. Thus, we believe that the hyperglycemia found in desynchronized gerbils may also result from a disturbance of the liver clock. Indeed, it has been shown in Wistar rats that the LD cycle mimicking the rotating shift-work with 8-h phase delay affects the expression of 'metabolic' genes (Per2, Bmal1, Rev-erba, Ppar $\alpha$, and Pdk4) in the liver [45].

The hyperglycemia obtained indicates also a disruption of carbohydrate metabolism. Histochemical analysis with PAS staining revealed hepatocytic glycogen depletion confirmed by the biochemical tissue assay, with 53\% reduction suggesting an association between hyperglycemia and glycogen depletion. This result could reflect either activation of the glycogenolytic pathway or an inhibition of the glycogenogenesis pathway.

Doi et al. found that mutation of the Clock gene or disruption of Per 2 gene expression leads to attenuated oscillations of hepatic glycogen and expression of glycogen synthase 2 (Gys2), the glycogenogenesis limiting enzyme [46]. In addition, disruption of Per2 gene expression alters glycogen accumulation in the liver and gluconeogenesis [47-49].

Hyperglycemia observed in shifted gerbils implies a preponderant action of glucagon. It is well known that stimulation of glycogenolysis in the liver increases glycemia [50]. Since the action of glucagon is observed under conditions of pressing energy needs [51], we believe that as feeding time is shortened, shifted gerbils are unable to synthesize enough glycogen. In this case, glycogen depletion could be due to insufficient amounts of ingested glucose and not to glycogenolysis. However, the shifted group ingested larger amounts of barley than control animals, which cannot explain the decrease in liver glycogen. Therefore, we suggest that because of Gerbillus tarabuli nocturnal habits, the short duration of the dark phase is not sufficient for the activation of glycogenogenesis enzymes. Indeed, it was reported that several genes encoding key enzymes of the carbohydrate metabolism display circadian variations in the liver [52-55].

We found that the disrupted circadian cycle has led to a decrease in triglyceride and cholesterol plasma levels. Liver is a central organ of lipid metabolism so that the histochemical Sudan Black B staining revealed only discrete cytoplasmic dispersed lipid inclusions and the lipid extractions assay showed decreased total hepatic lipids in shifted gerbils compared to controls.

Human studies showed that plasma triglyceride levels are increased in shift workers [56-58]. In mice kept in constant lighting conditions plasma lipid rhythm is abolished indicating the regulation of this metabolism by light signals [59]. Plasma triglycerides and cholesterol exhibit a diurnal rhythm with high levels at midnight in rats maintained in $12 \mathrm{~h} \mathrm{LD} \mathrm{cy-}$ cle [60]. Also in DD (constant darkness) conditions, several works indicate that mice lipid metabolism is rhythmically coordinated by the endogenous circadian clock [52]. Therefore, it seems that the phase shifting applied to gerbils has also affected their endogenous lipid metabolism rhythm. Indeed, Clock or Bmal1 mutant mice, develop hypertriglyceridemia and hypercholesterolemia [43, 61]. Similarly, mice lacking the Per2 gene have dyslipidemia [62].

In addition, the decrease in plasma lipid in shifted gerbils may be due to changes in the daily rhythm of eating behavior. Thus, it was found that a daily feeding rhythm is essential for maintaining the daily rhythm in TG secretion [63]. This proposal is consistent with the work of other authors [60, 64-66] who showed that changes in the daily rhythm of eating behavior modified or suppressed the daily rhythm of plasma triglycerides. Also, gene expression of enzymes such as adipose triglyceride lipase (ATGL), medium-chain acyl-CoA dehydrogenase [67] and lipoprotein lipase (LPL) (an enzyme that clears the circulation of TGs and releases free fatty acids for cellular absorption) [68] have been shown to exhibit circadian oscillations in various tissues. Moreover, it was reported that lipid and cholesterol absorption rates are higher during the active period and lower during the rest period in nocturnal mice [59].

Furthermore, synthesized cholesterol combines with apolipoproteins to be secreted and transported as HDLs or VLDLs [35, 59, 69]. Experiments on rats and mice suggest that the increase in nocturnal cholesterol in plasma is caused by changes in lipoproteins [60]. The liver is also involved in lipid metabolism by regulating lipoprotein synthesis, lipid uptake and conversion, besides de novo synthesis and oxidation of fatty acids [70]. 
Altogether this, and our data, may indicate that prolonged light phase caused a decrease in liver activity. The biochemical determination of total tissue lipids and the Sudan Black B staining revealed a lipid decrease in hepatocytes of shifted gerbils. This suggests that plasma lipid alterations might have been caused by changes in hepatic lipid metabolism.

\section{Impact of light/dark cycle disruption on the liver structure}

At the structural level, compared to the standard $12 \mathrm{~L} / 12 \mathrm{D}$ cycle, the shifted cycle led to a loss of the hepatic parenchyma architecture by the appearance of several lesional foci. These sites of inflammatory process combine sinusoid capillary dilation, Kupffer cells proliferation and leukocytes infiltration. The most probably causes of such structural alterations may be the activation of Kupffer cells which chemoatract neutrophils.

Kupffer cells and leukocytes secrete several inflammatory mediators, including cytokines [71]. These molecules play an active role in the tissue recruitment of neutrophils from circulation [72] and in the activation of Kupffer cells themselves [73]. The activation of Kupffer cells also leads to the release of reactive oxygen species (ROS) [74] that are important for normal functioning of the liver [75].

We also show in the shifted group an intense immunoreactivity of MPO essentially located in leukocytes and centrolobular hepatocytes. It is well known that MPO is a marker of neutrophil activation and tissue infiltration. Also many authors suggest that MPO expression is a reliable indicator of inflammation $[76,77]$ more sensitive than histopathological examination of tissues [78]. Indeed, local degranulation of neutrophils would induce the release of MPO into the extracellular matrix [79-81]. This proteolytic enzyme is responsible for the acidification of the environment [82] so that it adheres to cell membranes and produces hypochlorous acid $(\mathrm{HOCl})$ which easily passes the plasma membrane. That could explain the positive immunoreactivity of MPO in hepatocytes. Finally, $\mathrm{HOCl}$ exhaust intracellular glutathione [83] an important biological antioxidant [84].

Our observations also showed in the shifted gerbils an expansion of stellate cells and an increase in connective tissue within the hepatic parenchyma that may lead to hepatic fibrosis. This accumulation of connective tissue components may be caused by an imbalance between an increased synthesis of matrix components and a decrease in their degradation. Some studies proved that myeloperoxidase can stimu- late the production of extracellular matrix proteins by Kupffer cells. Also matrix alteration has been linked to the activation of stellate liver cells, a critical step in the development of liver fibrosis [85-88]. Indeed, stellate cells become the primary source of extracellular matrix accumulation in the liver during injury $[89,90]$.

\section{Conclusions}

As a whole, it appears that a chronic phase shifting (12 weeks) in Gerbillus tarabuli not only affects metabolic parameters, but it also alters liver architecture. The short duration of the nocturnal phase in our model lead to the accelerated development of hyperglycemia, some perturbations in serum lipid parameters (triglycerides and cholesterol) and a depletion of hepatocytic glycogen and lipid inclusions suggesting interference with the regulation of lipid and glucose hepatic metabolism. Interestingly, our morphological observations clearly implicate the effects of shifted LD cycle on the structure of liver tissue. Further studies should clarify the effect of a long-lasting disrupted LD cycle on the expression profiles of liver's clock genes under the same conditions in this species.

\section{Acknowledgments}

We are grateful to the Center Pierre and Marie Curie (CPMC) for hosting us to carry out the immunohistochemistry in particular Professor N. Chaher.

A special thank for Dr J. Falcon (UPMC and CNRS) for proofreading the manuscript, H. Touati for her help in statistical analysis part.

The authors wish to thank the participating members especially R. Hammi, as well as the Neurobiology Team (Faculty of Biological Sciences, Laboratory of Biology and Physiology of Organisms, USTHB, Algeria). We also thank all the personnel who helped directly and indirectly to the establishment of this work particularly A. Ben Saad.

\section{Contributors}

A. Derbouz Rouibate conducted the experimental part, the collection, the interpretation of data and wrote the first draft of the manuscript. N. Benhafri helped in the experimental part of the work. A. DekarMadoui contributed to the conception and design of the study, supervised the experimental part of the work, and participated in data analysis and the correction of the paper. S. Ouali-Hassenaoui participated in analyzing data and drafting the final version of manuscript. All authors contributed to manuscript revision, read and approved the submitted final version. 


\section{Funding}

This research was performed at the level of the Laboratory of Biology and Physiology of Organisms (LBPO), Faculty of Biological Sciences, USTHB, (Algiers, Algeria).

This work was supported by the General Direction of Scientific Research and Development of Technology (Ministry of Higher Education and Scientific Research, DGRSDT-MESRS), Algeria.

\section{Conflicts of interest}

The authors declare no conflict of interest.

\section{References}

1. Rosa RR, Bonnet MH, Bootzin RR, et al. Intervention factors for promoting adjustment to nightwork and shiftwork. Occup Med. 1990; 5(2):391-415. , indexed in Pubmed: 2203163.

2. Esseveldt Lv, Lehman M, Boer G. The suprachiasmatic nucleus and the circadian time-keeping system revisited. Brain Res Rev. 2000; 33(1): 34-77, doi: 10.1016/s0165-0173(00)00025-4.

3. Chou T, Scammell T, Gooley J, et al. Critical Role of Dorsomedial Hypothalamic Nucleus in a Wide Range of Behavioral Circadian Rhythms. J Neurosci. 2003; 23(33): 10691-10702, doi: 10.1523/jneurosci.23-33-10691.2003, indexed in Pubmed: 14627654.

4. Challet E. Horloges circadiennes, troubles métaboliques et chronobésité. Obésité. 2009; 4(1): 73-85, doi: 10.1007/ s11690-009-0172-6.

5. Ralph MR, Foster RG, Davis FC, et al. Transplanted suprachiasmatic nucleus determines circadian period. Science. 1990; 247(4945): 975-978, doi: 10.1126/science.2305266, indexed in Pubmed: 2305266.

6. Schibler U, Ripperger J, Brown SA. Peripheral circadian oscillators in mammals: time and food. J Biol Rhythms. 2003; 18(3): 250-260, doi: 10.1177/0748730403018003007, indexed in Pubmed: 12828282.

7. Balsalobre A, Damiola F, Schibler U. A Serum Shock Induces Circadian Gene Expression in Mammalian Tissue Culture Cells. Cell. 1998; 93(6): 929-937, doi: 10.1016/s00928674(00)81199-x.

8. Kumar Jha P, Challet E, Kalsbeek A. Circadian rhythms in glucose and lipid metabolism in nocturnal and diurnal mammals. Mol Cell Endocrinol. 2015; 418 Pt 1: 74-88, doi: 10.1016/j.mce.2015.01.024, indexed in Pubmed: 25662277.

9. Bray MS, Ratcliffe WF, Grenett MH, et al. Quantitative analysis of light-phase restricted feeding reveals metabolic dyssynchrony in mice. Int J Obes (Lond). 2013; 37(6): 843-852, doi: 10.1038/ijo.2012.137, indexed in Pubmed: 22907695.

10. Puttonen S, Härmä M, Hublin C. Shift work and cardiovascular disease - pathways from circadian stress to morbidity. Scand J Work Environ Health. 2010; 36(2): 96-108, doi: 10.5271/sjweh.2894, indexed in Pubmed: 20087536.

11. Fritschi L, Glass DC, Heyworth JS, et al. Hypotheses for mechanisms linking shiftwork and cancer. Med Hypotheses. 2011; 77(3): 430-436, doi: 10.1016/j.mehy.2011.06.002, indexed in Pubmed: 21723672.

12. Stevens RG. Light-at-night, circadian disruption and breast cancer: assessment of existing evidence. Int J Epidemiol. 2009; 38(4): 963-970, doi: 10.1093/ije/dyp178, indexed in Pubmed: 19380369.
13. Kohyama J. A newly proposed disease condition produced by light exposure during night: asynchronization. Brain Dev. 2009; 31(4): 255-273, doi: 10.1016/j.braindev.2008.07.006, indexed in Pubmed: 18757146.

14. Scheer FA, Hilton MF, Mantzoros CS, et al. Adverse metabolic and cardiovascular consequences of circadian misalignment. Proc Natl Acad Sci U S A. 2009; 106(11): 4453-4458, doi: 10.1073/pnas.0808180106, indexed in Pubmed: 19255424.

15. Bedrosian TA, Nelson RJ. Influence of the modern light environment on mood. Mol Psychiatry. 2013; 18(7): 751-757, doi: 10.1038/mp.2013.70, indexed in Pubmed: 23711982.

16. Karlsson B, Knutsson A, Lindahl B. Is there an association between shift work and having a metabolic syndrome? Results from a population based study of 27,485 people. Occup Environ Med. 2001; 58(11): 747-752, doi: 10.1136/oem.58.11.747, indexed in Pubmed: 11600731.

17. Knutsson A. Health disorders of shift workers. Occup Med (Lond). 2003; 53(2): 103-108, doi: 10.1093/occmed/kqg048, indexed in Pubmed: 12637594.

18. Hassid WZ, Abraham S. [7] Chemical procedures for analysis of polysaccharides. Methods Enzymol. 1957: 34-50, doi: 10.1016/s0076-6879(57)03345-5.

19. Trinder P. Determination of Glucose in Blood Using Glucose Oxidase with an Alternative Oxygen Acceptor. Ann Clin Biochem. 1969; 6(1): 24-27, doi: 10.1177/000456326900600108.

20. Folch J, Lees M SGHS. A simple method for the isolation on purification of total lipids from animal tissues. J Biol Chem. 1957; 226(1):497-235. , doi: 10.0000/www.jbc.org/226/1/497.

21. Martoja R, Martoja-Pierson M. Initiation aux techniques de l'histologie animale. Elsevier Masson.; 1967.

22. Albrecht U, Eichele G. The mammalian circadian clock. Curr Opin Genet Dev. 2003; 13(3): 271-277, doi: 10.1016/s0959437x(03)00055-8.

23. Reppert SM, Weaver DR. Molecular analysis of mammalian circadian rhythms. Annu Rev Physiol. 2001; 63: 647-676, doi: 10.1146/annurev.physiol.63.1.647, indexed in Pubmed: 11181971.

24. Mercer JG, Moar KM, Logie TJ, et al. Seasonally inappropriate body weight induced by food restriction: effect on hypothalamic gene expression in male Siberian hamsters. Endocrinology. 2001; 142(10): 4173-4181, doi: 10.1210/endo.142.10.8454, indexed in Pubmed: 11564670.

25. Huang Z, Liu Q, Peng Yu, et al. Circadian Rhythm Dysfunction Accelerates Disease Progression in a Mouse Model With Amyotrophic Lateral Sclerosis. Front Neurol. 2018; 9: 218, doi: 10.3389/fneur.2018.00218, indexed in Pubmed: 29740382.

26. McDonald RB, Hoban-Higgins TM, Ruhe RC, et al. Alterations in endogenous circadian rhythm of core temperature in senescent Fischer 344 rats. Am J Physiol. 1999; 276(3 Pt 2): R824-R830, doi: 10.1152/ajpregu.1999.276.3.r824, indexed in Pubmed: 10070144.

27. Sen S, Raingard H, Dumont S, et al. Ultradian feeding in mice not only affects the peripheral clock in the liver, but also the master clock in the brain. Chronobiol Int. 2017; 34(1): 17-36, doi: 10.1080/07420528.2016.1231689, indexed in Pubmed: 27668547.

28. Karatsoreos IN, Bhagat S, Bloss EB, et al. Disruption of circadian clocks has ramifications for metabolism, brain, and behavior. Proc Natl Acad Sci U S A. 2011; 108(4): 1657-1662, doi: 10.1073/pnas.1018375108, indexed in Pubmed: 21220317.

29. de Goede P, Sen S, Su Y, et al. An Ultradian Feeding Schedule in Rats Affects Metabolic Gene Expression in Liver, Brown Adipose Tissue and Skeletal Muscle with Only Mild Effects on Circadian Clocks. Int J Mol Sci. 2018; 19(10), doi: 10.3390/ ijms19103171, indexed in Pubmed: 30326619. 
30. Fonken LK, Workman JL, Walton JC, et al. Light at night increases body mass by shifting the time of food intake. Proc Natl Acad Sci U S A. 2010; 107(43): 18664-18669, doi: 10.1073/pnas.1008734107, indexed in Pubmed: 20937863.

31. Coomans CP, van den Berg SAA, Houben T, et al. Detrimental effects of constant light exposure and high-fat diet on circadian energy metabolism and insulin sensitivity. FASEB J. 2013; 27(4): 1721-1732, doi: 10.1096/fj.12-210898, indexed in Pubmed: 23303208.

32. Shi Sq, Ansari TS, McGuinness OP, et al. Circadian disruption leads to insulin resistance and obesity. Curr Biol. 2013; 23(5): 372-381, doi: 10.1016/j.cub.2013.01.048, indexed in Pubmed: 23434278.

33. Dauchy RT, Dauchy EM, Tirrell RP, et al. Dark-phase light contamination disrupts circadian rhythms in plasma measures of endocrine physiology and metabolism in rats. Comp Med. 2010; 60(5):348-356., indexed in Pubmed: 21262119.

34. Kettner NM, Voicu H, Finegold MJ, et al. Circadian Homeostasis of Liver Metabolism Suppresses Hepatocarcinogenesis. Cancer Cell. 2016; 30(6): 909-924, doi: 10.1016/j. ccell.2016.10.007, indexed in Pubmed: 27889186.

35. Challet E. Circadian clocks, food intake, and metabolism. Prog Mol Biol Transl Sci. 2013; 119: 105-135, doi: 10.1016 / B978-0-12-396971-2.00005-1, indexed in Pubmed: 23899596.

36. Stokkan KA, Yamazaki S, Tei H, et al. Entrainment of the circadian clock in the liver by feeding. Science. 2001; 291(5503): 490-493, doi: 10.1126/science.291.5503.490, indexed in $\mathrm{Pu}$ bmed: 11161204.

37. Tarquini R, Mazzoccoli G. Clock Genes, Metabolism, and Cardiovascular Risk. Heart Fail Clin. 2017; 13(4): 645-655, doi: 10.1016/j.hfc.2017.05.001, indexed in Pubmed: 28865774.

38. Manoogian ENC, Panda S. Circadian rhythms, time-restricted feeding, and healthy aging. Ageing Res Rev. 2017; 39: 59-67, doi: 10.1016/j.arr.2016.12.006, indexed in Pubmed: 28017879.

39. Damiola F, Le Minh N, Preitner N, et al. Restricted feeding uncouples circadian oscillators in peripheral tissues from the central pacemaker in the suprachiasmatic nucleus. Genes Dev. 2000; 14(23): 2950-2961, doi: 10.1101/gad.183500, indexed in Pubmed: 11114885.

40. Challet E, Malan A, Turek FW, et al. Daily variations of blood glucose, acid-base state and $\mathrm{PCO} 2$ in rats: effect of light exposure. Neurosci Lett. 2004; 355(1-2): 131-135, doi: 10.1016/j.neulet.2003.10.041, indexed in Pubmed: 14729252.

41. Gale JE, Cox HI, Qian J, et al. Disruption of circadian rhythms accelerates development of diabetes through pancreatic beta-cell loss and dysfunction. J Biol Rhythms. 2011; 26(5): 423-433, doi: 10.1177/0748730411416341, indexed in Pubmed: 21921296.

42. Nagai K, Nagai N, Sugahara K, et al. Circadian rhythms and energy metabolism with special reference to the suprachiasmatic nucleus. Neurosci Biobehav Rev. 1994; 18(4): 579-584, doi: 10.1016/0149-7634(94)90014-0.

43. Turek FW, Joshu C, Kohsaka A, et al. Obesity and metabolic syndrome in circadian Clock mutant mice. Science. 2005; 308(5724): 1043-1045, doi: 10.1126/science.1108750, indexed in Pubmed: 15845877.

44. Yamazaki S, Numano R, Abe M, et al. Resetting central and peripheral circadian oscillators in transgenic rats. Science. 2000; 288(5466): 682-685, doi: 10.1126/science.288.5466.682, indexed in Pubmed: 10784453.

45. Szántóová K, Zeman M, Veselá A, et al. Effect of phase delay lighting rotation schedule on daily expression of per2, bmal1, rev-erb $\alpha, \operatorname{ppar} \alpha$, and pdk 4 genes in the heart and liver of Wistar rats. Mol Cell Biochem. 2011; 348(1-2): 53-60, doi: 10.1007/s11010-010-0636-x, indexed in Pubmed: 21076970.
46. Doi R, Oishi K, Ishida N. CLOCK regulates circadian rhythms of hepatic glycogen synthesis through transcriptional activation of Gys2. J Biol Chem. 2010; 285(29): 22114-22121, doi: 10.1074/jbc.M110.110361, indexed in Pubmed: 20430893.

47. Schmutz I, Ripperger JA, Baeriswyl-Aebischer S, et al. The mammalian clock component PERIOD2 coordinates circadian output by interaction with nuclear receptors. Genes Dev. 2010; 24(4): 345-357, doi: 10.1101/gad.564110, indexed in Pubmed: 20159955.

48. Zhao Y, Zhang Y, Zhou M, et al. Loss of mPer2 increases plasma insulin levels by enhanced glucose-stimulated insulin secretion and impaired insulin clearance in mice. FEBS Lett. 2012; 586(9): 1306-1311, doi: 10.1016/j.febslet.2012.03.034, indexed in Pubmed: 22504074.

49. Zani F, Breasson L, Becattini B, et al. PER2 promotes glucose storage to liver glycogen during feeding and acute fasting by inducing Gys2 PTG and G L expression. Mol Metab. 2013; 2(3): 292-305, doi: 10.1016/j.molmet.2013.06.006, indexed in Pubmed: 24049741.

50. Voet D, Voet JG, Pratt CW. Principles of Biochemistry. John Wiley \& Sons. ; 2008.

51. Pearson MJ, Unger RH, Holland WL. Clinical Trials, Triumphs, and Tribulations of Glucagon Receptor Antagonists. Diabetes Care. 2016; 39(7): 1075-1077, doi: 10.2337/dci150033, indexed in Pubmed: 27330122.

52. Panda S, Antoch M, Miller B, et al. Coordinated Transcription of Key Pathways in the Mouse by the Circadian Clock. Cell. 2002; 109(3): 307-320, doi: 10.1016/s0092-8674(02)00722-5.

53. Storch K-F, Lipan O, Leykin I, et al. Extensive and divergent circadian gene expression in liver and heart. Nature. 2002; 417(6884):78-83. , doi: 10.1038/nature744, indexed in Pubmed: 11967526.

54. Lamia KA, Storch KF, Weitz CJ. Physiological significance of a peripheral tissue circadian clock. Proc Natl Acad Sci U S A. 2008; 105(39): 15172-15177, doi: 10.1073/pnas.0806717105, indexed in Pubmed: 18779586.

55. Reinke H, Asher G. Circadian Clock Control of Liver Metabolic Functions. Gastroenterology. 2016; 150(3): 574-580, doi: 10.1053/j.gastro.2015.11.043, indexed in Pubmed: 26657326.

56. Romon $M$, Nuttens $M C$, Fievet $C$, et al. Increased triglyceride levels in shift workers. Am J Med. 1992; 93(3): 259-262, doi: 10.1016/0002-9343(92)90230-9.

57. Itani O, Kaneita Y, Tokiya M, et al. Short sleep duration, shift work, and actual days taken off work are predictive life-style risk factors for new-onset metabolic syndrome: a seven-year cohort study of 40,000 male workers. Sleep Med. 2017; 39: 87-94, doi: 10.1016/j.sleep.2017.07.027, indexed in Pubmed: 29157594.

58. Lu YC, Wang CP, Yu TH, et al. Shift work is associated with metabolic syndrome in male steel workers-the role of resistin and WBC count-related metabolic derangements. Diabetol Metab Syndr. 2017; 9: 83, doi: 10.1186/s13098-017-0283-4, indexed in Pubmed: 29075331.

59. Pan X, Hussain MM. Clock is important for food and circadian regulation of macronutrient absorption in mice. J Lipid Res. 2009; 50(9): 1800-1813, doi: 10.1194/jlr.M900085-JLR200, indexed in Pubmed: 19387090.

60. Pan X, Hussain MM. Diurnal regulation of microsomal triglyceride transfer protein and plasma lipid levels. J Biol Chem. 2007; 282(34): 24707-24719, doi: 10.1074/jbc.M701305200, indexed in Pubmed: 17575276.

61. Rudic RD, McNamara P, Curtis AM, et al. BMAL1 and CLOCK, two essential components of the circadian clock, are involved in glucose homeostasis. PLoS Biol. 2004; 2(11): e377, doi: 10.1371/journal.pbio.0020377, indexed in Pubmed: 15523558. 
62. Grimaldi B, Bellet MM, Katada S, et al. PER2 controls lipid metabolism by direct regulation of PPAR $\gamma$. Cell Metab. 2010; 12(5): 509-520, doi: 10.1016/j.cmet.2010.10.005, indexed in Pubmed: 21035761.

63. Su Y, Foppen E, Mansur Machado FS, et al. The role of the daily feeding rhythm in the regulation of the day/night rhythm in triglyceride secretion in rats. Chronobiol Int. 2018; 35(7): 885-895, doi: 10.1080/07420528.2018.1438456, indexed in Pubmed: 29446660.

64. Pan X, Munshi MK, Iqbal J, et al. Circadian regulation of intestinal lipid absorption by apolipoprotein AIV involves forkhead transcription factors $\mathrm{A} 2$ and $\mathrm{O} 1$ and microsomal triglyceride transfer protein. J Biol Chem. 2013; 288(28): 20464-20476, doi: 10.1074/jbc.M113.473454, indexed in Pubmed: 23729668.

65. Shamsi NA, Salkeld MD, Rattanatray L, et al. Metabolic consequences of timed feeding in mice. Physiol Behav. 2014; 128: 188-201, doi: 10.1016/j.physbeh.2014.02.021, indexed in Pubmed: 24534172.

66. Yasumoto Y, Hashimoto C, Nakao R, et al. Short-term feeding at the wrong time is sufficient to desynchronize peripheral clocks and induce obesity with hyperphagia, physical inactivity and metabolic disorders in mice. Metabolism. 2016; 65(5): 714-727, doi: 10.1016/j.metabol.2016.02.003, indexed in Pubmed: 27085778.

67. Bailey SM, Udoh US, Young ME. Circadian regulation of metabolism. J Endocrinol. 2014; 222(2): R75-R96, doi: 10.1530/ JOE-14-0200, indexed in Pubmed: 24928941.

68. Gimble JM, Floyd ZE. Fat circadian biology. J Appl Physiol (1985). 2009; 107(5): 1629-1637, doi: 10.1152/japplphysiol.00090.2009, indexed in Pubmed: 19470701.

69. Sassolas A, Cartier R. Hypocholesterolemias: causes and diagnosis. Ann Biol Clin. 1999; 57(5):555-60. , indexed in Pubmed: 10518057.

70. Adamovich Y, Aviram R, Asher G. The emerging roles of lipids in circadian control. Biochim Biophys Acta. 2015; 1851(8): 1017-1025, doi: 10.1016/j.bbalip.2014.11.013, indexed in Pubmed: 25483623.

71. Mathurin P, Poynard T. Pharmacological treatment for alcoholic hepatitis and cirrhosis. Ethanol and the Liver. 2013: 592-613, doi: 10.3109/9780203301388-31.

72. SAWADOGO A, DIB N, CALES P. Physiopathologie de la cirrhose et de ses complications. Réanimation. 2007; 16(7-8): 557-562, doi: 10.1016/j.reaurg.2007.09.001.

73. Suffredini A, Fantuzzi G, Badolato R, et al. New insights into the biology of the acute phase response. J Clin Immunol. 1999; 19(4): 203-214, doi: 10.1023/a:1020563913045.

74. Gregory SH, Wing EJ. Neutrophil-Kupffer cell interaction: a critical component of host defenses to systemic bacterial infections. J Leukoc Biol. 2002; 72(2):239-248. , doi: 10.1189/jlb.72.2.239.

75. Wick M, Leithauser F, Reimann J. The Hepatic Immune System. Crit Rev Immunol. 2002; 22(1): 57, doi: 10.1615/critrevimmunol.v22.11.30.

76. Jawhara S, Thuru X, Standaert-Vitse A, et al. Colonization of mice by Candida albicans is promoted by chemically induced colitis and augments inflammatory responses through galectin-3. J Infect Dis. 2008; 197(7): 972-980, doi: 10.1086/528990, indexed in Pubmed: 18419533.

77. Kim HW, Uh DK, Yoon SY, et al. Low-frequency electroacupuncture suppresses carrageenan-induced paw inflamma- tion in mice via sympathetic post-ganglionic neurons, while high-frequency EA suppression is mediated by the sympathoadrenal medullary axis. Brain Res Bull. 2008; 75(5): 698-705, doi: 10.1016/j.brainresbull.2007.11.015, indexed in Pubmed: 18355649.

78. Faith M, Sukumaran A, Pulimood AB, et al. How reliable an indicator of inflammation is myeloperoxidase activity? Clin Chim Acta. 2008; 396(1-2): 23-25, doi: 10.1016/j. cca.2008.06.016, indexed in Pubmed: 18619953.

79. McConnico RS, Weinstock D, Poston ME, et al. Myeloperoxidase activity of the large intestine in an equine model of acute colitis. Am J Vet Res. 1999; 60(7): 807-813. , indexed in Pubmed: 10407471.

80. Zhang C, Patel R, Eiserich JP, et al. Endothelial dysfunction is induced by proinflammatory oxidant hypochlorous acid. Am J Physiol Heart Circ Physiol. 2001; 281(4): H1469-H1475, doi: 10.1152/ajpheart.2001.281.4.H1469, indexed in Pubmed: 11557534.

81. Hoy A, Leininger-Muller B, Kutter D, et al. Growing significance of myeloperoxidase in non-infectious diseases. Clin Chem Lab Med. 2002; 40(1): 2-8, doi: 10.1515/ CCLM.2002.002, indexed in Pubmed: 11916266.

82. Heinecke J. Mechanisms of oxidative damage by myeloperoxidase in atherosclerosis and other inflammatory disorders. J Lab Clin Med. 1999; 133(4): 321-325, doi: 10.1016/s00222143(99)90061-6.

83. Nahon P, Sutton A, Rufat P, et al. Myeloperoxidase and superoxide dismutase 2 polymorphisms comodulate the risk of hepatocellular carcinoma and death in alcoholic cirrhosis. Hepatology. 2009; 50(5): 1484-1493, doi: 10.1002/hep.23187, indexed in Pubmed: 19731237.

84. Winterbourn CC, Brennan SO. Characterization of the oxidation products of the reaction between reduced glutathione and hypochlorous acid. Biochem J. 1997; 326 ( Pt 1): 87-92, doi: 10.1042/bj3260087, indexed in Pubmed: 9337854.

85. Jarnagin WR, Rockey DC, Koteliansky VE, et al. Expression of variant fibronectins in wound healing: cellular source and biological activity of the EIIIA segment in rat hepatic fibrogenesis. J Cell Biol. 1994; 127(6 Pt 2): 2037-2048, doi: 10.1083/jcb.127.6.2037, indexed in Pubmed: 7806580.

86. Gressner AM, Bachem MG. Molecular mechanisms of liver fibrogenesis--a homage to the role of activated fat-storing cells. Digestion. 1995; 56(5): 335-346, doi: 10.1159/000201257, indexed in Pubmed: 8549875.

87. Bekheet IW, Madkour ME, Ghaffar N, et al. The Role of Myeloperoxidase in Hepatitis C Virus Infection and Associated Liver Cirrhosis. Open Trop Med J. 2009; 2(1): 1-7, doi: 10.2174/1874315300902010001.

88. Abdel-Hamid M, Nada O, Ellakwa DS, et al. Role of Myeloperoxidase in hepatitis $\mathrm{C}$ virus related hepatocellular carcinoma. Meta Gene. 2018; 18: 1-8, doi: 10.1016/j. mgene.2018.07.008.

89. Friedman SL. Hepatic stellate cells: protean, multifunctional, and enigmatic cells of the liver. Physiol Rev. 2008; 88(1): 125-172, doi: 10.1152/physrev.00013.2007, indexed in Pubmed: 18195085 .

90. DeLeve LD, Jaeschke H, Kalra VK, et al. 15th International Symposium on Cells of the Hepatic Sinusoid, 2010. Liver Int. 2011; 31(6): 762-772, doi: 10.1111/j.1478-3231.2011.02527.x, indexed in Pubmed: 21645207.

Submitted: 3 February, 2020

Accepted after reviews: 13 September, 2020 Available as AoP: 22 September, 2020 